\title{
The Kallikrates vs the Kapodistrias Reforms in Greece: A Story of Moderate Success
}

\author{
VASILIKI KALIMERI
}

$\frac{\text { DE }}{\mathrm{G}} \stackrel{\text { DE GRUYTER }}{\text { OPEN }}$

Politics in Central Europe (ISSN: 1801-3422)

Vol. 14 , No. 1

DOI: $10.2478 /$ pce-2018-0003

\begin{abstract}
This article aims to analyse and evaluate the implementation of Greek local government reforms based on the surrounding economic and political situation. The main two reforms in question, the Kapodistrias and the Kallikrates programmes, both tried to modernise the state under the influence of Greece's European Union membership. Though revolutionary for its era, the Kapodistrias programme soon reached its limits. The newer Kallikrates reform, adopted under pressure from the European Union and the International Monetary Fund due to the economic crisis, has sought to reduce public spending and create a leaner state. Nevertheless, largely because of its external origins, even this more recent reform has failed to improve the deteriorating Greek local government sector.
\end{abstract}

Keywords: Greece, local government, reforms, municipalities, prefectures, regions, economic crisis, Council of Europe

\section{Introduction}

Decentralisation is defined by the World Bank as the transfer of authority and responsibilities for public services from central governments to regional governments, quasi-independent government organisations and/or the private sector. Article 101, paragraph 1 of the Greek Constitution establishes a "decentralisation" principle covering the administration of the state: "Administration of the state shall be organised according to a principle of decentralisation." Article 102 paragraph 1 further specifies: "The administration of local affairs shall be performed by first- and second-tier local authorities. In the administration of local affairs, there is a presumption of local authorities' competence." 
At the outset, we should note that over the last three decades in Greece, decentralisation has been pursued through the Kapoditrias and Kallikrates programmes, two different reforms at local government level. The more recent Kallikrates project represents a major administrative reform for Greece. The associated law, Act no. 3852/2010 was first applied in the November 2010 local elections and came into full effect in January 2011. The Kallikrates reform has introduced a comprehensive decentralisation process, rearranging the distribution of power in the Greek state in favour of local government. Its two central pillars are the advancement of local and regional authorities and the establishment of institutional bodies including regional and municipal advisory and executive committees.

\section{The development of local self-government in Greece: a historical analysis}

Since the establishment of the Greek state in 1830, civil service corruption, bureaucracy and clientelism have been seen as the main problems facing the Greek public sector. ${ }^{1}$ Particularly since the country's accession to the European Union in 1981, another ongoing obstacle affecting development has been the weak and inefficient implementation of adopted European legislation. For these reasons, assessing the success of any reform calls for consideration of whether it has significantly changed the domestic legal situation.

The modern Greek state was inspired by the French Napoleonic institutional model of territorial organisation. Even the Constitution adopted through the 1821 Greek revolution - that is, before the establishment of the modern state reflected the idea of a state organised by principles of local self-governance and popular participation.

A closer historical analysis suggests that under the 1912 territorial system, municipalities (demoi) and communities (koinotites) were the only self-governing entities. These local authorities appear to have been rather small with limited powers and insufficient financial resources. ${ }^{2}$ The country was further divided into prefectures (nomarchia), which were deconcentrated outposts of the central state headed by a prefect (nomarchis) appointed by the government.

At the beginning of the 1980s, Greece remained a centralised (Athens-centric) state, highly corrupt and controlled by clientelistic practices. Local authorities continued to be seen as a danger to the central state.

The first attempt to introduce effective administrative reforms took place in the mid-80s in connection with Greece's European Union membership. The European Union was then introducing a programme of service liberalisation

1 The state's extensive collaboration with powerful private companies has been a particular concern.

2 Eighty-five percent of these entities had fewer than 1000 residents. 
and privatisation and Greece was obliged to adopt new policies to qualify for European funds. Many EU states were also taking steps to reform their public sectors, influenced by a new public management theory whose aim was to decrease public spending and install new management practices at local level. In contrast, Greece's forays into these reforms were very delayed, coming only in the late 1990s when other European countries were beginning to experience the negative consequences of this doctrine.

After two failed attempts at establishing an upper level of decentralised government with general powers (1913-1953 and 1970-1973), Greece adopted Act no. 1622/1986, introducing thirteen administrative regions. This system was finally installed under Presidential Decree no. 51 on 6 March 1987. The regions in question lacked broad powers, having been set up to coordinate regional development so that Greece could take advantage of European structural funds. ${ }^{3}$ They were controlled by a regional secretary-general appointed by the government.

In the meantime, the modernising of the public sector had emerged as a complete failure. The sector had gradually been expanded and the civil service was highly politicised with patronage being a very common practice. Strong labour unions also appeared and blocked many reforms. The majority of policies represented reforms that had been externally driven due to the Europeanisation process without any real knowledge of what they were intended to improve (Manojlovic 2011). ${ }^{4}$

Eventually, Greece's local self-government system was formed through two successive reform processes, the Kapodistrias and Kallikrates programmes, which reduced the huge number of municipalities, replaced prefectures with regions as the second level of local government and transferred a set of powers from the central government to the municipalities and regions.

\section{The Kapodistrias reform}

Until 1994, municipalities across both urban and rural areas were the only decentralised authorities in Greece. ${ }^{5}$ These local authorities lacked the resources, however, to undertake any significant tasks. Under Act No. 2218/1994, the prefectures also became self-governing authorities, and certain state tasks were

3 This reorgranisation of the state was a precondition for the receipt of these funds.

4 Manojlovic (2011) puts it: "[T] hese reforms proved to be exterior reforms in which new institutions were created and former existing institutions transformed, but the performance of the entire public sector remained untouched. Interior reforms that comprise the change of administrative culture, as well as the change in the way public sector operates, were not conducted" (p. 41).

5 As well as municipalities, Greece contained provinces (nomoi), however beginning from 1833, they were directed by provincial governors (nomarchoi), who were government appointees. In 1994, the provinces were turned into territorial authorities with elected councils; the provincial governors (now leaders of the successful parties) became their heads. 
deconcentrated and transferred to regional level. In other words, the regions took over the role that the prefectures had played until then. Prefects were elected and their administration was reinforced through a set of jurisdictions. Seen from one standpoint, these 1994 reforms were in fact fairly radical: not only did they convert the provinces into territorial authorities with elected assemblies and leaders but they endowed them almost immediately with all the powers previously exercised by appointed provincial governors. On the other hand, these new authorities remained financially dependent on the central state budget.

As part of this framework, the government adopted the Kapodistrias programme (Act No. 2539/1997), which aimed to reduce the number of local authorities, create stronger municipalities equipped to handle new tasks, promote local development and provide modern-style social services to the public. In concrete terms, this called for a reorganisation of institutions, powers, staff and financial resources.

Under the Kapodistrias reforms, local government was comprised of two completely independent levels of power. The first level contained 900 municipalities and 134 communities, all of which had full administrative autonomy. ${ }^{6}$ These municipalities were run by a mayor, a deputy mayor, a municipal council and a mayoral committee elected for four years through direct universal suffrage. The second level consisted of fifty self-governing prefectures, three of which were supra-prefectures made up of large geographical clusters (for instance, the Athens-Piraeus supra-prefecture). These prefectures were deconcentrated entities headed by an elected prefect, a prefectural council and a prefectural committee; the legality of their decisions and actions was to be overseen by the thirteen regions. The highest regional authority was a secretary-general appointed by Greece's Council of Ministers on the Minister of Interior's recommendation. During this period, the province system was also abolished.

The Kapodistrias reforms converted local institutions into municipal authorities at provincial level and developed a decentralised state administration at regional level. Subsequent governments - especially the Karamanlis government of 2004 and 2007 - set out to achieve more efficient administrative reforms, adopting new policies including the reorganisation of local administration (and the local self-government system) under a broad and ambitious programme known as the "re-founding of the state." This policy introduced innovative regulations around different aspects of local participation including local referenda, rights to information and to lodge petitions, municipal citizens' charters and an annual accountability requirement for local authorities.

6 The Kapodistrias reforms (Act no. 2539/1997) amalgamated 5755 municipalities and rural communities into 900 larger municipalities and 134 expanded communities but did not upgrade the powers of these amalgamated municipalities and communities. As a result, the number of first-tier local authorities was reduced from 5775 to 1033. 
In the meantime, other measures had been taken to upgrade the local public sector. Among them was another ambitious programme known as Politeia, which sought to enhance structural reforms to the organisation, processes and activities of public administration and facilitate citizen participation. Its main achievement was the creation of non-stop "citizen service centres" (KEP) where citizens could seek out any service. As part of the state's fight against corruption, a number of special inspection bodies were set up including an administrative inspectorate, a financial inspectorate and a financial crime crackdown body. ${ }^{7}$ These bodies were tasked with performing regular and ad hoc inspections to ensure efficient and transparent administration. Furthermore, in 1998, a Greek ombudsman was appointed to mediate between citizens and the public administration. This entity remains responsible for investigating specific administrative acts and omissions by government departments and public agencies.

Although the Kapodistrias plan introduced some changes to the local government system, it did not complete the process of decentralising power and reinforcing local institutions. This was because too much authority was still vested in the central government. As a result, Greece remained one of the most centralised countries in Europe.

\section{The Kallikrates reform}

A third stage of local government reform started in 2010 after the breakdown of the Greek economic system. A new initiative was launched by socialist party PASOK after its victory in the 2009 elections. The new government's reforms aimed to abolish small municipalities, which had been starved of funds and left unable to perform their tasks, and to reduce the number of government employees. In this context, the Kallikrates programme was adopted with the goal of not only creating a smaller state but cutting public spending in line with ongoing proposals from the European Union and the International Monetary Fund. ${ }^{8}$ This reform was an essential first step for the creation of independent, transparent and reliable domestic structures and the pursuit of cost-cutting and effective governance. Significantly, these were also preconditions for Greece's receipt of funds from the Troika - that is, the IMF, the EU and the European Central Bank.

In fact, the need for this reform was tied in other important ways to Greece's participation in international and European organisations. In general, participation of this kind necessarily leads to the delegation of substantial power to governance levels beyond the state. Policy-making, rule-making and

7 The financial crime crackdown body was known as the Civil Service Internal Inspectorate. It was established in 2002.

8 See Act no. 3852/2010 (ФEK 87/B/7. 6. 2010) “New Architecture for Self-Governance and Decentralisa-

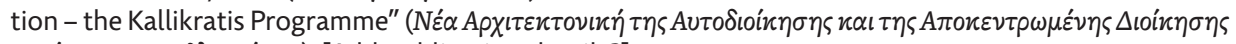

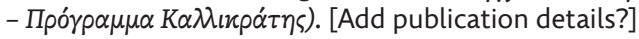


planning are, for example, largely delegated to the global and regional levels of governance. In addition, even after the Kapodistrias reforms, local entities in Greece continued to have limited autonomy from a tax standpoint; they remained largely dependent on central government funds. This meant that they could not contribute to strengthening the Greek economy. This was an unacceptable situation for the Committee of the Regions and the Directorate of Regional Policy of the European Commission, whose criteria required Greece to reform its administrative system and set up effective decentralised local entities with real powers and adequate funds.

Under the Kallikrates reforms, which remain in place today, the first and lowest level of power has been assigned to the municipalities (dhmos), whose number has been reduced from 914 to 325 . The 325 municipalities have been further divided into local communities and municipal communities (the latter are known as "communi-cities" and have a population of fewer than 2000 citizens). In this way, the Greek municipalities have achieved a population of 31,000 residents in line with other municipalities in the European Union. Administration of these municipalities falls to a mayor, a deputy mayor, a municipal council, ${ }^{9}$ an economic affairs committee, a quality-of-life committee ${ }^{10}$ and an executive committee. ${ }^{11}$ Municipalities with a population exceeding 10,000 citizens also have an advisory committee made up of local community groups. ${ }^{12}$

But the main innovation of the Kallikrates reforms has been the establishment of the regions as an "intermediate" level of government between municipalities and the state. The 54 prefectures, which were the second level of local self-government, have been abolished and their role taken up by various regions (periféreies). These regions are self-governing territorial legal entities, and they form the upper division of local government. In each region, regional authorities (Perifereiakes Enotites) have been set up within the boundaries of the former prefectures and the once insular provinces (eparchy). Two metropolitan regions have also been introduced (in Attice and Thessaloniki/Central Thessaloniki respectively) in order to promote environmental protection and improve quality of life and urban and land planning in these areas. The main tasks of these new

9 This council has between thirteen and forty-seven members depending on the size of the municipality.

10 The quality-of-life committee has been set up in municipalities with a population of over 10,000 residents. It consists of the mayor and a number of municipal councilors elected by the municipal council. Its responsibilities include urban planning, land planning, environmental issues, business and shop licensing and deciding on street market spaces and outdoor trading places. The committee also has a special responsibility for enhancing quality of life in the municipality.

11 The executive committee is described as a joint executive and coordinating body that is responsible for preparing and implementing the municipality's work programme. It is also charged with monitoring and implementing municipal decisions. Executive committees have been set up in municipalities with more than one deputy mayor. They are presided over by the mayor and composed of deputy mayors.

12 A second advisory committee in these municipalities brings together representatives of local stakeholders such as businesses, trade unions, chambers of commerce and NGOs. 
entities include implementing European development policies and promoting regional development projects and competition.

Each self-governing region is administered by an elected regional general secretary ${ }^{13}$ a deputy general secretary, a regional council, an executive committee and an economic and social affairs committee. ${ }^{14}$ There is also a regional advisory committee with members drawn from business, industry and labour groups and a regional ombudsman for business and citizens' affairs. The region's head (Peripheriarchs) is responsible for protecting the public interest, monitoring implementation of regional development plans and performing other regional duties transparently and efficiently. The regional council takes care of all regional issues not assigned by law to other regional bodies.

For these purposes, the regions have been endowed with administrative powers and given their own budgets (to be allocated by the state and implemented by regional governors) and their own staff. At the same time, they lack any independent legal personality and remain an echelon of the state administration, which is answerable to the central government.

Furthermore, seven general directorates have also been created. They are not local self-governing authorities but perform the role previously played by the regions as deconcentrated state powers with a state-appointed general secretary and an unelected advisory council. The directorates are responsible for town and urban planning and environment, forestry, migration, citizenship and energy policies. They are also meant to oversee actions and decisions taken at the first and second levels of local government and, in particular, to ensure legality and transparency across their administration. For this reason, a separate independent service has been installed within each directorate to supervise local government; it is run by an auditor who reviews the legality of all actions and decisions at the two self-governing levels.

In addition to all these measures, the Kallikrates reforms have reduced the minimum age of election to 18 years for municipal and regional councillors and 21 years for the mayor and the general secretary, thus enabling the active participation of young people in local affairs. In another key change to the mandate, the term of office for local authorities has become five years. Since 2014, subnational elections have taken place at the same time as European parliament elections, with elected officials receiving a five-year mandate. Moreover, the right to vote and to stand for office as municipal councillors and deputy mayors has been extended to legal immigrants, with the aim of promoting their integration into local communi-cities. Each municipality also has a council responsible for migrant integration and a local ombudsman (Symparastatis) for business

13 The direct election of governors is intended to increase citizens' participation in the region.

14 The economic committee is responsible for financial oversight and the regular monitoring of the municipality's economic performance. It designs the municipal budget and proposes potential charges, fees and levies to the municipal council. 
and citizens' affairs. This ombudsman serves for five years and is authorised to investigate claims of improper administration and draft an annual report on the protection of citizens' rights by municipal authorities.

As part of their programme of abolishing political appointments and increasing public sector transparency, the Kallikrates reforms have also tried to set up very strict controls over municipal and regional spending under the supervision of the Court of Auditors. Financial committees and executive committees have been established to deal with government corruption and professionalise financial accounting. Local government spending commitments are tightly controlled by the Ministry of Finance so that the state can ensure numerical targets/quantitative criteria. ${ }^{15}$ Furthermore, for transparency reasons, each local government decision must be published and made accessible online. ${ }^{16}$ This is also meant to build citizens' trust in the actions of local authorities.

Nevertheless, in spite of all this progress, there have been persistent problems including a lack of communication and interaction between the national and subnational levels of power. Another key issue is the lack of statutory powers of municipal authorities, preventing them from regulating local affairs. Moreover, some of the most important public services including education, health and social protection systems remain subject to direct and comprehensive control by the central government.

\section{Reasons for the partial failure of the Kallikrates reform}

It is known that the economic and financial environment has a critical impact on the decentralisation process. As far as the Kallikrates programme is concerned, we should bear in mind that the implementation of this reform coincided with the start of the economic crisis, which has had profound effects on Greece. For this reason, the Kallikrates project must also be assessed in the general context of the financial crisis and the Troika's demands to reduce spending and the size of the public sector.

In fact, Greece adopted all of these measures under the pressure of several memoranda produced by the Troika. ${ }^{17}$ Particularly in the first and second

15 Under Articles 275 and 276 of the law establishing the Kallikrates programme, the Court of Auditors has the power to supervise the financial activities of local authorities (municipalities and regions). The court should perform a preventive audit of all expenses incurred by municipalities, regions and their legal bodies (excluding school committees) as well as public utilities and municipal water supply/sewerage enterprises and municipal limited companies. These rules apply regardless of population size.

16 Another achievement has been the open government initiative, introduced in 2009 just before Greece's signing of a related Troika memorandum. This programme requires the online publication of certain calls for open positions. The Diavgeia programme - diavgeia means transparency in Greek - aims to make all acts by government and public administrative bodies available for revew online.

17 There were three specific memoranda:

1. the Memorandum on Economic and Financial Policies (MEFP)

2. the Technical Memorandum of Understanding (TMU) 
of these documents, there were specific provisions concerning local government's role in ensuring overall austerity. The Memorandum on Economic and Financial Policies (MEFP) called for the reorganisation of sub-central levels of government in order to reduce the number of local administrative divisions and elected/appointed officials. This memorandum also specified that "[p]arliament should adopt legislation to reform the public sector at the local level, notably by amalgamating municipalities, prefectures and regions in order to reduce operating costs and the wages bill." Another memorandum endorsed by the Greek government advised that "the bulk of the change will be achieved through spending cuts that aim to permanently streamline the state and improve government efficiency by winding up entities that no longer deliver a cost-effective public service and through targeted cuts to public sector employment." Greece's adoption of these memoranda has posed a lot of problems; the most important concern is that the new measures arose from external pressures and were put into place quite fast without the necessary consultation at the local and regional levels. ${ }^{18}$

In 2015, the Council of Europe's Congress of Local and Regional Authorities visited Greece in order to monitor the implementation of the European Charter of Local Self-government. The Congress also outlined some problems in the complex implementation of the new reform.

The Congress expressed concerns about the role of - and indeed need for - the seven new state authorities (directorates general), noting that the distribution of power and responsibilities remained unclear among the state administration, regions and municipalities. The Congress also highlighted local entities' lack of statutory powers, observing that they did not have the authority to regulate local affairs. ${ }^{19}$ This recent monitoring report has also made clear that the Greek regions cannot be considered to be "regions" in the context of the Council of Europe Reference Framework for Regional Democracy; rather, they represent a second tier of local government. This is because they lack regulatory powers as self-organising entities and have limited power as tax authorities. While the

3. the Memorandum of Understanding on Specific Economic Policy Conditionality

18 Article 4 paragraph 6 of the European Charter of Local Self-government reads: "Local authorities shall be consulted, insofar as possible, in due time and in an appropriate way in the planning and decision-making processes for all matters which concern them directly." In just one example of the problem, the geographical boundaries prescribed do not correspond with actual boundaries in some cases.

19 The European Charter of Local Self-government refers to the right and capacity of local authorities to "regulate and manage a substantial share of public affairs under their own responsibility and in the interests of the local population" (Art. 3, para. 1). The term "substantial" remains open to interpretation, however. Moreover, this provision refers to local authorities in general rather than the separate levels of local authority in a particular state. In the final analysis, it is up to the national legislator to determine - directly or indirectly - what local matters comprise - and it may decide to broaden or narrow this definition for general policy reasons. 
regions may establish their own organisational charter and define internal administrative rules, this must be done within the strict framework of national laws.

The most significant point raised by the report, however, is the lack of adequate concomitant funding for the transfer of powers to local authorities, which rely mainly on state funds. In fact, throughout the financial crisis, the Greek central government has tried to transfer some of its powers to the local level without providing adequate funding. This is despite the recognition in Article 9 of the European Charter of Local Self-government that "local authorities' financial resources shall be commensurate with the responsibilities provided for by the Constitution and the law." What we have seen has, thus, been more like the devolution of austerity policies. Furthermore, during the first year of the implementation of the Kallikrates reforms, the central government cut funding to local authorities by $25 \%$ or 1.2 billion euros. Increasingly, local and regional authorities have faced cuts of $60 \%$ to the central government budget for this kind of funding. According to one explanation raised several times by rapporteurs, the implementation of the reform has been deeply affected by the economic crisis.

\section{Conclusion}

The main purpose of the article has been to offer a historical perspective on the development of the local self-government system in Greece. To this end, I have mapped the progress achieved with a special focus on the two latest system reforms, analysing both the reasons for their adoption and the implementation process. In fact, both the Kapodistrias and Kallikrates programmes reorganised not just the Greek local government system but the overall administration of the country. Both aspired to modernise the state by upgrading local government's role in the regional planning process and they led to a few important achievements in terms of spatial planning and social capital. The Kallikrates reform, in particular, put special emphasis on state efficiency; through a bottom-up process, it aimed to create economies of scale, improve the management of human and financial resources and deliver professional quality services. Ultimately, however, any improvements to social capital were extremely limited, perhaps because the reform's implementation began during a major financial crisis in Greece.

Despite the abolition of Greece's self-governing prefectures and remaining provinces and the transfer of its thirteen regions from the decentralised state to local government, the state remains a distinctly unitary entity with no real split in the atom of sovereignty. Even the term "region" is deceptive: these regions are simply administrative districts, and apart from certain ministerial agencies, the regional governor is the only administrative authority. Furthermore, local authorities do not have tax-generating powers. Another problem 
is clearly the country's new directorates general, which highlight the central government's goal of decentralising systems while retaining all power in its own hands. From this point of view, the reforms have not had the expected results.

Given all these factors, the most important next steps may be to limit the responsibilities of the directorates general, assign more tasks and powers to local and regional self-governing authorities and push for financial decentralisation in order to fight corruption and clientelism. Reducing the number of public servants may also prove beneficial (Torres Pereira - Mosler-Tornstrom 2015).

We may conclude that neither the Kapodistrias nor the Kallikrates reform took account of the particularity of the Greek case and they therefore failed to achieve the expected success. It may be that the entire Greek public sector needs reforming in addition to any changes to local self-government. ${ }^{20}$ The question that persists is whether the latest reforms, driven by European pressure and prepared in a hurry because of the economic crisis, are Greece's last chance to break the inertia and finally change its public administration system. As such, the challenge for Greece is now to "Hellenise" the measures required by the European Union and the International Monetary Fund; if it can't do this, any reforms will fail. The present crisis presents a once-in-a-generation chance for change, and we may need to wait a few years to see whether new reforms succeed.

\section{References}

Akrivopoulou, C. - Dimitropoulos, G. - Koutnatzis, S.-I. (3/2012): The Kallikratis Program, The Influence of International and European Policies on the Reforms of Greek Local Government, Istituzioni del Federalismo: 653

Andreadis, I. - Chadjipadelis. T.: The 2010 Elections for the Greek Regional Authorities, http:// www.polres.gr/en/sites/default/files/PSA2011-GPSG.pdf

Code of Civil Servants (1999):Official Gazette of the Hellenic Republic, Issue No A/19, 9. 2. 1999. Act no. 2683/1999: www.oecd.org/dataoecd/61/14/35526160.pdf

Constitution of Greece, as revised by a parliamentary resolution on 27 May 2008 of the Eighth Revisionary Parliament: http://www.hellenicparliament.gr/UserFiles/f3c70a23-7696-49db9148-f24dce6a27c8/001-156\%20aggliko.pdf

loannidis, P. (2015): Decentralization, Local Government Reforms and Perceptions of Local Actors: The Greek Case. MPRA Paper No. 66420

Hlepas, N. - Getimis. P. (2011): Greece: Prefectures, in Loughlin, J. - Hendriks, F. - Lidström, A. The Oxford Handbook of Local and Regional Democracy in Europe, 410-433. Oxford University Press.

20 To reform the entire system, the government will need to consider areas such as the civil service and the pension system. 
Hlepas, N. (2010): The impact of local government reforms in Greece: A critical overview, in Impact of Reforms on Public Administration in the Balkan States. National Experiences in Public Administration in the Balkans from Weberian Bureaucracy to New Public Management, Workshop, Athens, EPLO.

Manojlovic, R. (2011): Public Sector Reforms in Greece: Uncertain Outcome of 2010 Reforms. Croatian \& Comparative Public Administration 11(2):337-377.

Panara, C. - Varney, M. (2013): Local Government in Europe. The Fourth level in the EU multilayered system of governance, Routledge,

Rhodio, G. - Van Nistelrooij, L. (2001): Report on the situation of local and regional democracy in Greece.

Sarafopoulos, G. - Hazakis, K. - loannidis, P. (2014): Modeling economic growth policy interaction with local government reform: Evidence from Eastern Macedonia and Thrace, in Journal of Economics and Business 17(2).

Skamnakis, C. (2011): Smaller Governments, Less Social Policy? Paper delivered at the Social Policy Association annual conference, Lincoln, UK, http://www.social-policy.org.uk/lincoln2011/ Skamnakis\%20P3.pdf.

Skordas, A. (2010): Greece's Financial Crisis : The Politics of Resolution and Reform, Woodrow Wilson International Center for Scholars, Southeast Europe Project, 24 March 2010.

Spanou, C. (2003): L'administration grecque en mutation: le double défi de la démocratisation et de l'européanisation, Pôle Sud, 18(1):51-62.

Torres Pereira, A. - Mosler-Tornstrom, G. (2015): Local and regional democracy in Greece. Local and regional monitoring committee, Council of Europe, 28th session, Strasbourg, 24-26 March 2015.

Vamvakas, P. - Kulich-Vamvakas, C., European Economic Crisis: Enhancing Good Regional Governance in the EU? The Case of Greece: http://www.umdcipe.org/conferences/DecliningMiddleClassesSpain/Papers/Petros.pdf

Vasiliki Kalimeri, Ph.D., studied Law at the Aristotle University of Thessaloniki/ Greece and the University of Paris 1 Panthéon-Sorbonne. She works as the legal policy assistant in the European Commission and Attorney-at-law (Paris Bar Association). E-mail:vasiliki.klm@gmail.com 